\title{
Seasonal variation of the effect of high-carbohydrate and high-protein diets on the intermediate metabolism of Parastacus brasiliensis (Crustacea, Decapoda, Parastacidae) maintained in the laboratory
}

\author{
Bibiana K. Dutra ${ }^{1}$, Karina M. da Silva ${ }^{1}$, Caroline Zank ${ }^{1}$, Maria R. Conter ${ }^{2}$ \& Guendalina T. Oliveira ${ }^{1}$ \\ 1. Departamento de Ciências Morfofisiológicas, Laboratório de Fisiologia da Conservação, Faculdade de Biociências, Pontifícia Universidade \\ Católica do Rio Grande do Sul, Av. Ipiranga, 6681 Prédio 12C Sala 270, 90619-900 Porto Alegre, RS, Brazil. (guendato@ pucrs.br) \\ 2. Departamento de Biodiversidade, Laboratório de Fisiologia da Conservação, Faculdade de Biociências, Pontifícia Universidade Católica \\ do Rio Grande do Sul, Av. Ipiranga, 6681 Prédio 12C Sala 270, 90619-900 Porto Alegre, RS, Brazil.
}

\begin{abstract}
The goal of this study was to evaluate the effect of a high-carbohydrate diet (HC) and a high-protein diet (HP) on the metabolism of the crayfish Parastacus brasiliensis (Von Martens, 1869), collected in different seasons and maintained in the laboratory for 15 days. Crayfish were collected monthly from January 2002 to January 2004 at São Francisco de Paula, Southern Brazil, in Guarapirá stream. In the laboratory, the animals were kept submerged in aquariums under controlled conditions. They were fed ad libitum, for 15 days with either a HC or HP diet. At the end of this period, haemolymph samples were collected, as were hepatopancreas, gills, and abdominal muscle that were removed for determination of glycogen, free glucose, lipids, and triglycerides. The haemolymph samples were used for determination of glucose, proteins, lipids, and triglycerides. Statistical analysis (ANOVA) revealed significant seasonal differences in biochemical composition in crayfish maintained on HC or HP diets. Independent of the diets offered to the animals and the controlled conditions for 15 days, the indications of seasonality were unchanged. The observed changes seemed to be related to the reproductive period. Moreover, the HC diet increased all energy reserves in adult parastacids, which may aid in reproduction.
\end{abstract}

KEYWORDS. Crayfish, experimental culture, diet, metabolism, seasonality.

RESUMO. Variações sazonais do efeito de uma dieta rica em carboidrato e rica em proteínas no metabolismo intermediário de Parastacus brasiliensis (Crustacea, Decapoda, Parastacidae) mantidos em laboratório. O objetivo deste estudo foi avaliar o efeito da dieta rica em carboidratos (HC) e da dieta rica em proteínas (HP) sobre o metabolismo do Parastacus brasiliensis (Von Martens, 1869) coletados em diferentes estações e mantidos durante 15 dias em laboratório. Os lagostins foram coletados mensalmente de Janeiro de 2002 a Janeiro de 2004 em São Francisco de Paula, Sul do Brasil, no riacho Guarapirá. No laboratório, os animais foram mantidos submersos em aquários sob condições controladas. Eles foram alimentados ad libitum por 15 dias com a dieta HC ou HP. Após o final do período, as amostras de hemolinfa foram coletadas, assim como o hepatopâncreas, as brânquias e o músculo abdominal foram removidos para a determinação do glicogênio, glicose livre, lipídios e triglicerídeos. As amostras de hemolinfa foram usadas para a determinação da glicose, proteínas, lipídios e triglicerídeos. As análises estatísticas (ANOVA) revelaram uma diferença sazonal significativa na composição bioquímica nos lagostins mantidos com dieta HC ou HP. Independente da dieta oferecida para os animais e das condições controladas por 15 dias, não foi possível alterar os perfis metabólicos encontrados sazonalmente nos animais em campo. As mudanças observadas parecem estar relacionadas ao período reprodutivo. Além disso, a dieta $\mathrm{HC}$ aumentou todas as reservas energéticas nos parastacídeos adultos, o que pode auxiliar na reprodução.

PALAVRAS-CHAVE. Lagostim, cultivo experimental, dieta, metabolismo e sazonalidade.

Recently, in the region of São Francisco de Paula, Southern Brazil, at an altitude of 900 meters a.s.l., a population of Parastacus brasiliensis (Von Martens, 1869) was found in the Pró-Mata Center for Research and Nature Conservation (CPCN). This is the first record in Brazil of a freshwater crayfish living at high altitude and low temperatures. Its accelerated growth and rapid maturation, together with its ease of handling, make this species a good candidate for experimental culture programs. It is especially important to establish the requirements for dietary proteins according to the condition of the organism (e.g. stage, size) and culture conditions (e.g. density, temperature, pH) (CAMPAÑATorRes et al., 2005). Some recent studies have been conducted on the nutritional requirements of freshwater crayfishes (MEAdE \& WATTS, 1995; CORTÉs-JACINTO et al., 2003, 2004; RodRíGUEZ-GonZÁLEZ et al., 2006), as well as on the replacement of fish meal by different protein sources (Thompson et al., 2004; GARCía-Ulloa et al., 2003; MuZINIC et al., 2004). However, for $P$. brasiliensis to be cultured commercially, it is necessary to have a good understanding of culture techniques as well as the nutritional requirements and metabolic behavior of this species.

Cultivated crayfish are of high economic value in some countries, mainly in Europe, Chile, the southern United States and Australia. In Brazil, freshwater crayfish are not usually consumed, perhaps because of the regional distribution of the species and also the difficulty in harvesting the natural populations.

The family Parastacidae is represented in South America by the genera Parastacus, Hulex, 1879, Samastacus Riek, 1971, and Virilastacus Hobbs, 1991. Only members of Parastacus occur in Brazil, preferentially in marshy lentic environments on the plains, and in small, slowly flowing streams (BUCKUP \& Rossi, 1980; FrIES, 1980; FonTOURA \& BuCKUP, 1989). Most species construct underground habitations in the form of simple or branched tunnels that reach groundwater level and have one or more openings on the surface. The animals are nocturnal, 
when they leave their burrows to hunt for food in or near the water (Buckup, 1999).

Study of the intermediate metabolism in crustaceans has revealed the existence of wide inter- and intra-specific variability, which makes it difficult to determine a standard metabolic profile (OliveIRa et al., 2003). This variability can occur because of multiple factors, such as habitat, stage in the molt cycle, sexual maturity (especially in females), feeding state, available food, and seasonality, resulting in different patterns of metabolic response (SCHIRF et al., 1987; KUCHARSKI \& DA Silva, 1991b; Oliveira et al., 2007).

Crustaceans contain high concentrations of lipids, although they have no differentiated adipose tissue, storing lipids mainly in muscle tissue and the hepatopancreas (O'CONNOR \& GILBERT, 1968; CHANG \& O'ConNor, 1983; Herreid \& Full, 1988; KuCHARSKI \& DA Silva, 1991a). During periods of high energy demand, such as molting and gametogenesis, large amounts of lipids are mobilized, especially from the hepatopancreas (KuCharski \& Da Silva, 1991a; Rosa \& Nunes, 2003b; OliveIRA et al., 2007).

Glucose is the principal monosaccharide present in the haemolymph of crustaceans, and it serves six main purposes: synthesis of mucopolysaccharides, synthesis of chitin, synthesis of ribose and nicotinamide adenine dinucleotide phosphate reduced (NADPH), formation of pyruvate, and synthesis of glycogen (CHANG \& O'Connor, 1983; Herreid \& Full, 1988). Stable glucose haemolymph levels are essential for the regular functioning of the nervous, muscle, and reproductive systems (VERRI et al., 2001; RADFORD et al., 2005). Glucose can be accumulated in the form of free glucose and glycogen in the hepatopancreas and in other tissues, such as the muscles and the gills (VINAGRE \& DA Silva, 1992; OliveIRA et al., 2003).

In crustaceans, glycogen is stored mainly in the muscles, hepatopancreas, gills, and hemocytes; however, the storage locations vary among different species (Parvathy, 1971; Johnston \& Davies, 1972; Herreid \& FULL, 1988). The stored glycogen is utilized in adaptation to molting, hypoxia and/or anoxia, osmoregulation, growth, reproduction and during fasting periods (CHANG \& O'ConNOR, 1983; KuCharski \& Silva, 1991a, 1991b; Rosa \& NunEs, 2003a; Oliveira et al., 2001 and 2004b).

The muscle is apparently the main protein-storage location in crustaceans. Proteins are a structural, functional, and energy constituent of tissues and play an important role in spawning, fertilization and normal development of embryo in decapods (GARCIA-GUERRERO et al., 2003; RodriguEz-GonZÁlez et al., 2006). Other studies have demonstrated variation in protein content during ovarian development in crustaceans. These variations may result from increased biosynthesis of several proteins, including enzymes, hormones, and lipoproteins involved in gonadal maturation (YEHEZKEL et al., 2000; RosA \& NunEs, 2003a, b).

The present study aims to study the effect of a high-carbohydrate diet (HC) or high-protein diet (HP) on seasonal variations in energy metabolism in different tissues of individuals of the freshwater crayfish Parastacus brasiliensis (Von Martens, 1869) maintained for 15 days in the laboratory. The purpose was to obtain basic physiological data to support adequate management of these populations.

\section{MATERIAL AND METHODS}

The animals were cared for in accordance with guidelines such as the Guide for the Care and Use of Laboratory Animals (NATIONAL RESEARCH COUNCIL (1985)). The animals were used with the permission of the Ethics Committee of the Pontifícia Universidade Católica do Rio Grande do Sul (License 0002/03).

The animals were collected in a stream in the PróMata CPCN, an area about 4,500 ha and between 600 and $900 \mathrm{~m}$ a.s.l., located in the municipality of San Francisco de Paula, Rio Grande do Sul, Brazil between $29^{\circ} 27^{\prime}$ $29^{\circ} 35^{\prime} \mathrm{S}$ and $50^{\circ} 08^{\prime}-50^{\circ} 15^{\prime} \mathrm{W}$. Trapping was done in four capture periods (Spring, Summer, Autumn, and Winter), for two years. Adults in stage C or D of the intermolt cycle (DRACH \& TCHERNIGONTZEFF, 1967) were transported in containers with cold water $\left(5^{\circ} \mathrm{C}\right)$ to the Laboratory of Conservation Physiology of PUCRS, where they were placed in aerated aquariums for 24 hours without food.

After this 24-hour period, the animals were kept submerged in aerated aquariums, with an average temperature of $25 \pm 1^{\circ} \mathrm{C}$ and a photoperiod of $14: 10$ hours light/dark. The crayfish were divided into two groups, which were fed ad libitum in late afternoon, when most of the animals were active, for a period of 15 days. They were fed one of two diets. The high-carbohydrate diet (HC) consisted of cooked white rice (protein $3.34 \%$, fat $0.45 \%$, fiber $0.30 \%$, water content $61.33 \%$, ashes $0.02 \%$ and carbohydrates $34.56 \%$ ). The high-protein diet (HP) consisted of commercial pelletized ration (protein $21.0 \%$, fiber $4.0 \%$, water content $12.0 \%$, ether extract $8.0 \%$, mineral $10.0 \%$, calcium $2.5 \%$ and phosphorus $1.0 \%$ ).

After the 15-day period, samples of haemolymph were collected with a syringe containing $10 \%$ potassium oxalate as an anti-clotting substance, and were frozen for later determination of glucose, total proteins, total lipids, and triglycerides. The animals were cryoanesthetized, weighed on an electronic balance $( \pm 0.001)$, and then stored frozen at $-80^{\circ} \mathrm{C}$ until they were used to determine the biochemical parameters.

The crayfish were not separated by sex. In parastacids, the male genital pore is located on the coxopodite of pereiopod 5 , and the female pore on the coxopodite of pereiopod 3. The presence of both pairs of genital pores may indicate hermaphroditism, and makes it difficult to determine the sex in this species. Also, the previous calcification of the genital opening (pore) can be present in immature females (ALMEIDA \& BUCKUP, 1999; Silva-Castiglioni, 2007).

The metabolic parameters of the haemolymph sample of each animal were determined in triplicate. The number of crayfish tested in each season ranged from 20 to 30 .

a. Glucose levels were measured by the glucoseoxidase method, using a Bioclin Kit (glucose GOD-CLIN) Results are expressed in $\mathrm{mmol} / \mathrm{L}$.

b. Total lipids were measured by the sulfophosphovanillin method (FRINGS \& DuNN, 1970), with the results expressed in $\mathrm{mg} / \mathrm{dL}$. 
c. Triglycerides were measured using a Biodiagnostic Kit (GPO Trinder). Results are expressed in $\mathrm{mg} / \mathrm{dL}$.

d. Proteins were measured following the method described by LOWRY et al. (1951), using bovine albumin (Sigma Chemical Co., St. Louis, Missouri, U.S.A.) as the reference substance. Results are expressed in $\mathrm{mg} / \mathrm{mL}$.

The metabolic parameters of the tissue sample from each animal were determined in triplicate. The number of crayfish assayed in each season ranged from 20 to 30 .

a. Lipids were extracted from tissue weighed and then homogenized with an Omni Mixer Homogenizer in a $2: 1(\mathrm{v} / \mathrm{v})$ chloroform-methanol solution, according to Folch et al. (1957). Total lipids in this homogenate were determined by the sulfophosphovanillin method (FRINGS \& Dunn, 1970; Meyer \& Walther, 1980). This method consists of oxidizing cellular lipids to small fragments after chemical digestion with hot concentrated sulfuric acid. After the addition of a solution of vanillin and phosphoric acid, a red complex is formed, which is measured with a spectrophometer $(530 \mathrm{~nm})$. Triglycerides were measured by the reactions of lipase, glycerokinase, 1-P-glycerol oxidase, and peroxidase enzymes (Biodiagnostic Kit / GPO Trinder). Results are expressed as $\mathrm{mg} / \mathrm{g}$ of tissue.

b. Glycogen was extracted from tissues following the method described by VAN HANDEL (1965). Glycogen levels in the animals were determined as glucose equivalent (glucose-oxidase method), after acidic hydrolysis $(\mathrm{HCl})$ and neutralization $\left(\mathrm{Na}_{2} \mathrm{CO}_{3}\right)$, following the method of GEARY et al. (1981). Glucose was quantified using a Biodiagnostic kit (glucose-oxidase). Results are presented as $\mathrm{mg} / \mathrm{g}$ of tissue.

c. Free glucose was determined according to CARR $\&$ NefF (1984). The tissue samples were weighed and homogenized with Ultra-Turrax in a $100 \mathrm{mM}$ sodium citrate solution, boiled for 10 minutes, agitated, cooled to ambient temperature, and stored at $20^{\circ} \mathrm{C}$ for at most one week. To separate the lipid fraction, the samples were mixed in a $2: 1(\mathrm{v} / \mathrm{v})$ chloroform-methanol solution in the ratio of 2:1 (w/v) and centrifuged for 10 minutes at 2500 rpm. The free glucose concentration was determined by the glucose-oxidase colorimetric method (Biodiagnostic Kit) in the intermediate fraction obtained after centrifugation. The results are expressed as $\mathrm{mg} / \mathrm{g}$ of tissue.

For statistical analysis of the seasonal variations, a one-way ANOVA test was used, followed by a Bonferroni test. For comparison between diets and seasons a two-way ANOVA was used. All the metabolic parameters were homogeneous (Levene test), and were normally distributed (Kolmogorov-Smirnov test). The significance level adopted was 5\%. All the tests were done with the program SPSS 11.5 for Windows.

\section{RESULTS}

The dietary treatments had no significant influence on survival, which over the period of the experiments was equal to or greater than $90 \%$. The diets did not significantly affect growth, measured as weight gain $(\mathrm{p}>0.05)$.
Glucose concentrations in $P$. brasiliensis that received the high-carbohydrate diet (HC) showed no seasonal variation (Fig. 1). In the crayfish that received the high-protein diet (HP), glucose concentration rose in Autumn, and decreased in other seasons (Fig. 1). There was a significant difference between the glucose contents of the crayfish that received the $\mathrm{HC}$ diet and those on the HP diet $(\mathrm{p}<0.05)$.

In the $\mathrm{HC}$ crayfish, the protein concentration rose in Autumn, and gradually decreased in the following seasons (4.7-fold); in the HP group, proteins reached minimum values in Summer, and a maximum in Autumn $(50 \%)$. There was no significant difference $(\mathrm{p}>0.05)$ between total protein concentrations in the crayfish on the two diets (Fig. 2).

The animals fed with high carbohydrate diets showed maximum concentrations of lipids in Autumn and Winter, and minimum levels in Spring and Summer. The group that received the high-protein diet showed a maximum hemolymph concentration of total lipids in Summer and Autumn and subsequent decreases in the other seasons. There was a significant difference $(p<0.05)$ in total lipid contents between the crayfish on the two diets (Fig. 3).

In $\mathrm{HC}$ crayfish there were no significant seasonal variations in triglyceride levels in the haemolymph (Fig. 4). However, in HP animals, triglyceride concentrations

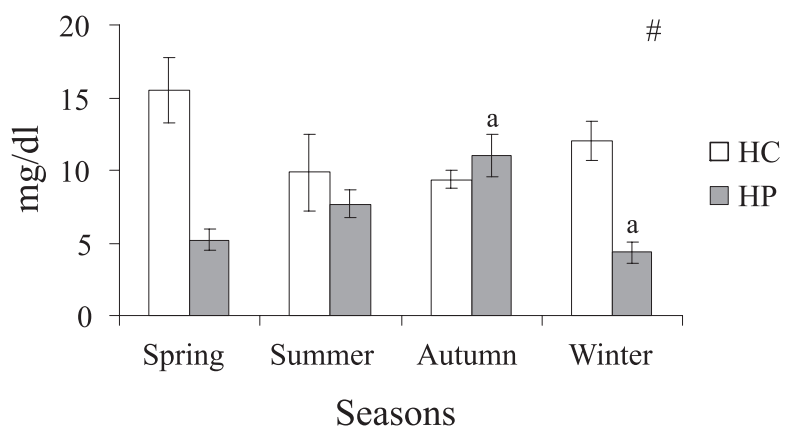

Fig. 1. Seasonal concentration of glucose in the haemolymph of Parastacus brasiliensis (Von Martens, 1869) maintained on a highcarbohydrate (HC) or high-protein (HP) diet. Columns represent the mean, and bars represent the standard error of the mean. Results are expressed in $\mathrm{mg} / \mathrm{dL}$. The same letter represents a significant difference between the seasons. \# significant difference between diets.

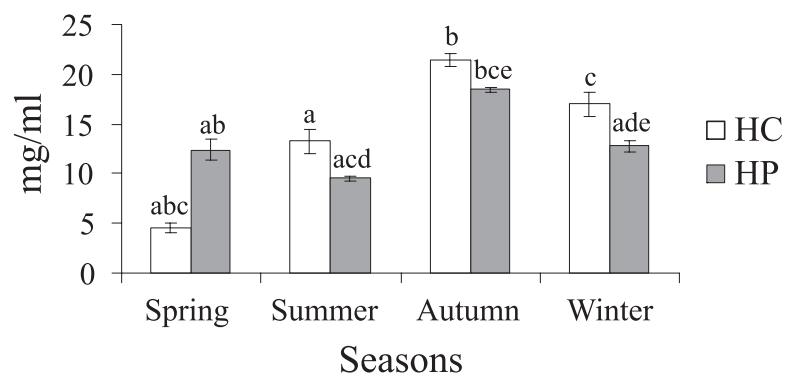

Fig. 2. Seasonal concentration of total proteins in the haemolymph of Parastacus brasiliensis (Von Martens, 1869) maintained on a high-carbohydrate (HC) or high-protein (HP) diet. Columns represent the mean, and bars represent the standard error of the mean. Results are expressed in $\mathrm{mg} / \mathrm{mL}$. The same letter represents a significant difference between the seasons. 
rose in Winter and Spring, and decreased in Summer and Autumn. There was a significant difference in triglyceride contents between the animals on the two diets $(\mathrm{p}<0.05)$.

The free glucose in the hepatopancreas of HC crayfish showed the highest values in Winter and decreased 2.6-fold in Summer (Tab. I). In the HP group, free glucose concentration rose in Winter and gradually decreased in the following seasons. There was a significant difference $(\mathrm{p}<0.05)$ in free-glucose content between the HC and HP animals. Glycogen levels increased in $\mathrm{HC}$ animals in the Summer and decreased 50-fold in Autumn (Tab. I). In the HP animals, glycogen increased significantly in Winter, and decreased in Spring and Summer. There was a significant difference between the glycogen contents in the two groups $(\mathrm{p}<0.05)$. The concentrations of total lipids of the $\mathrm{HC}$ animals rose in Autumn and fell to their lowest value in Summer. However, the HP animals showed the highest values of total lipids in Winter, with a 2.7-fold decrease in Spring; lipid levels in the hepatopancreas gradually increased in the subsequent seasons (Tab. I). There was no significant difference $(p>0.05)$ between total lipid content in the two groups. In the HC animals, triglycerides rose in Spring, decreased 21-fold in Summer, and then rose again in Autumn and Winter. In the HP crayfish, triglycerides rose in Summer, followed by a 4-fold decrease in Spring (Tab. I). There was a significant difference $(\mathrm{p}<0.05)$ between the triglyceride contents in the two groups.

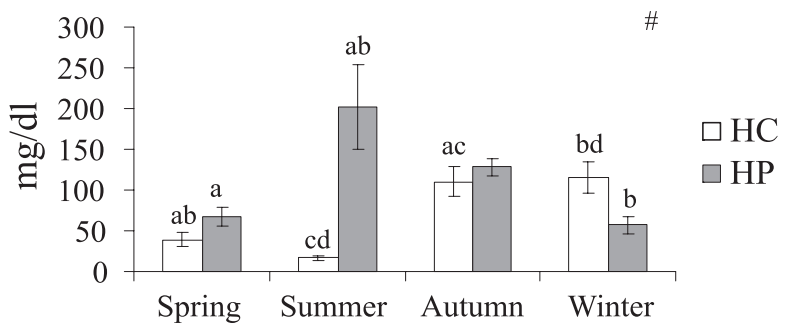

Seasons

Fig. 3. Seasonal concentration of total lipids in the haemolymph of Parastacus brasiliensis (Von Martens, 1869) maintained on a high-carbohydrate (HC) or high-protein (HP) diet. Columns represent the mean, and bars represent the standard error of the mean. Results are expressed in $\mathrm{mg} / \mathrm{dL}$. The same letter represents a significant difference between the seasons; \# a significant difference between diets.
The concentrations of free glucose of the HC animals showed no seasonal variation in the gills; however, the free glucose levels in gills of the HP crayfish rose in Autumn and Winter, and decreased 2.3-fold in Spring (Tab. II). There was no significant difference ( $>0.05)$ in free glucose content between the two groups. The animals that received the HC diet showed no seasonal variation in glycogen content in the gills; the crayfish fed the HP diet showed the highest values in Winter, and decreased in Spring (Tab. II). There was no significant difference ( $p>0.05)$ in glycogen content between the two groups. In the $\mathrm{HC}$ group, the content of total lipids in the gills showed no seasonal variation; however, levels of triglycerides were highest in Spring and decreased in Summer (Tab. II). In HP animals, levels of total lipids rose in Winter or Autumn and decreased approximately 18-fold in Spring; whereas triglycerides were highest in Summer and lowest in Spring (Tab. II). There was a significant difference $(p<0.05)$ between total lipids and triglycerides content in animals fed the two diets.

The levels of free glucose in muscle tissue showed seasonal variation only in the crayfish fed the HP diet, in which free glucose was highest in Winter and lowest in Summer (approximately 1.9-fold). There was a significant difference $(\mathrm{p}<0.05)$ in free glucose content between the crayfish fed the two diets (Tab. III). In HC animals, glycogen rose in Summer, and decreased in Autumn and the other seasons. The HP crayfish showed the highest

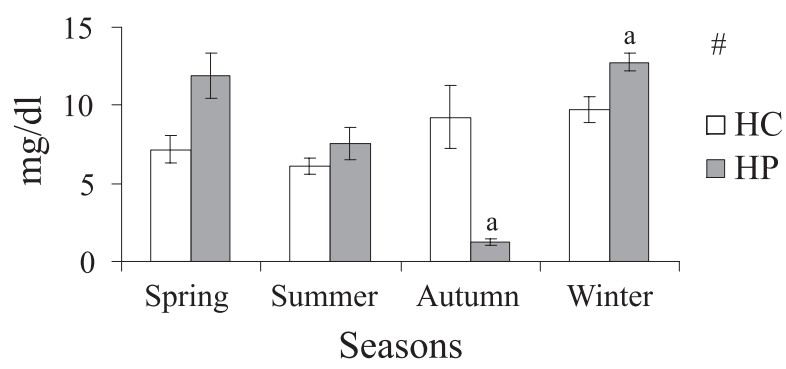

Fig. 4. Seasonal concentration of triglycerides in the haemolymph of Parastacus brasiliensis (Von Martens, 1869) maintained on a high-carbohydrate (HC) or high-protein (HP) diet. Columns represent the mean, and bars represent the standard error of the mean. Results are expressed in $\mathrm{mg} / \mathrm{dL}$. The same letter represents a significant difference between the seasons; \# a significant difference between diets.

Table I. Seasonal concentration of free glucose $(\mathrm{mg} / \mathrm{g})$, glycogen $(\mathrm{mg} / \mathrm{g})$, total lipids $(\mathrm{mg} / \mathrm{g})$, and triglycerides $(\mathrm{mg} / \mathrm{g})$ in the hepatopancreas of Parastacus brasiliensis (Von Martens, 1869) maintained on a high-carbohydrate (HC) or high-protein (HP) diet. All results represent the mean \pm standard error of the mean, and are expressed in $\mathrm{mg} / \mathrm{g}$. The same letter represents a significant difference between the seasons; \# a significant difference between diets.

\begin{tabular}{lcccc}
\hline Hepatopancreas & Spring & Summer & Autumn & Winter \\
\hline HC DIET & & & & \\
Free Glucose $^{\#}$ & $0.1151 \pm 0.0245$ & $0.0492 \pm 0.0083^{\mathrm{a}}$ & $0.07984 \pm 0.004$ & $0.1295 \pm 0.0221^{\mathrm{a}}$ \\
Glycogen $^{\text {Total Lipids }}$ & $5.4426 \pm 1.0529^{\mathrm{ad}}$ & $29.271 \pm 5.8648^{\mathrm{abc}}$ & $0.5824 \pm 0.2249^{\mathrm{bde}}$ & $3.9429 \pm 1.2127^{\mathrm{ce}}$ \\
Triglycerides & $12.602 \pm 3.6393$ & $7.9223 \pm 1.7824^{\mathrm{a}}$ & $47.292 \pm 15.358^{\mathrm{a}}$ & $20.962 \pm 4.3420$ \\
HP DIET & $9.1672 \pm 4.8282$ & $0.4332 \pm 0.1735$ & $5.1286 \pm 1.3932$ & $2.5674 \pm 0.7882$ \\
Free Glucose & & & & \\
Glycogen & $0.0240 \pm 0.0058^{\mathrm{a}}$ & $0.0306 \pm 0.0081^{\mathrm{b}}$ & $0.0506 \pm 0.0068$ & $0.0668 \pm 0.0079^{\mathrm{ab}}$ \\
Total Lipids & $0.0026 \pm 0.0005^{\mathrm{a}}$ & $0.0011 \pm 0.0002^{\mathrm{b}}$ & $0.0029 \pm 0.0008^{\mathrm{c}}$ & $0.0143 \pm 0.0022^{\mathrm{abc}}$ \\
Triglycerides & $13.458 \pm 0.8849^{\mathrm{a}}$ & $29.853 \pm 6.4509$ & $21.734 \pm 1.9200^{\mathrm{b}}$ & $36.130 \pm 3.4781^{\mathrm{ab}}$ \\
\hline
\end{tabular}


Table II. Seasonal concentrations of free glucose (mg/g), glycogen (mg/g), total lipids (mg/g), and triglycerides (mg/g) in the gills of Parastacus brasiliensis (Von Martens, 1869) maintained on a high-carbohydrate (HC) or high-protein (HP) diet. All results represent the mean \pm standard error of the mean, and are expressed in $\mathrm{mg} / \mathrm{g}$. The same letter represents a significant difference between the seasons; \# a significant difference between diets.

\begin{tabular}{|c|c|c|c|c|}
\hline Gills & Spring & Summer & Autumn & Winter \\
\hline \multicolumn{5}{|l|}{ HC DIET } \\
\hline Free Glucose & $0.0297 \pm 0.0067$ & $0.0821 \pm 0.0052$ & $0.0339 \pm 0.0029$ & $0.0359 \pm 0.0049$ \\
\hline Glycogen ${ }^{\#}$ & $3.2591 \pm 0.8098$ & $4.6721 \pm 0.6005$ & $3.2158 \pm 0.6485$ & $4.6895 \pm 0.6874$ \\
\hline Total Lipids $\#$ & $3.7480 \pm 1.8419$ & $2.2367 \pm 0.7206$ & $10.056 \pm 3.6571$ & $4.3298 \pm 1.6789$ \\
\hline Triglycerides ${ }^{\#}$ & $2.7627 \pm 1.3988^{a}$ & $0.1149 \pm 0.0328^{\mathrm{abc}}$ & $2.0437 \pm 1.1889^{\mathrm{b}}$ & $1.0554 \pm 0.4781^{\mathrm{c}}$ \\
\hline \multicolumn{5}{|l|}{ HP DIET } \\
\hline Free Glucose & $0.0093 \pm 0.0014^{\mathrm{ac}}$ & $0.0155 \pm 0.0035^{\mathrm{bd}}$ & $0.0214 \pm 0.0010^{\mathrm{ab}}$ & $0.0213 \pm 0.0026^{\mathrm{cd}}$ \\
\hline Glycogen & $0.0068 \pm 0.0005^{\mathrm{a}}$ & $0.0088 \pm 0.0004^{\mathrm{b}}$ & $0.0173 \pm 0.0026$ & $0.0269 \pm 0.0035^{\mathrm{ab}}$ \\
\hline Total Lipids & $1.4582 \pm 0.3111^{\mathrm{abc}}$ & $12.149 \pm 7.3819^{\mathrm{a}}$ & $14.387 \pm 6.9949^{\mathrm{b}}$ & $18.051 \pm 3.5233^{\mathrm{c}}$ \\
\hline Triglycerides & $0.1150 \pm 0.0267^{\mathrm{a}}$ & $3.1393 \pm 1.089^{\mathrm{abc}}$ & $0.9412 \pm 0.1876^{b}$ & $1.3456 \pm 0.4099^{c}$ \\
\hline
\end{tabular}

Table III. Seasonal concentrations of free glucose $(\mathrm{mg} / \mathrm{g})$, glycogen $(\mathrm{mg} / \mathrm{g})$, total lipids (mg/g), and triglycerides (mg/g) in the abdominal muscle of Parastacus brasiliensis (Von Martens, 1869) maintained on a high-carbohydrate (HC) or high-protein (HP) diet. All results represent the mean \pm standard error of the mean, and are expressed in $\mathrm{mg} / \mathrm{g}$. The same letter represents a significant difference between the seasons; \# a significant difference between diets.

\begin{tabular}{lccc}
\hline Muscle & Spring & Summer & Autumn \\
\hline HC DIET & $0.0389 \pm 0.0061$ & $0.0356 \pm 0.0044$ & $0.0651 \pm 0.0323$ \\
Free Glucose $^{\#}$ & $2.0599 \pm 0.3474^{\mathrm{a}}$ & $7.3386 \pm 1.3336^{\mathrm{abc}}$ & $1.4198 \pm 0.1741^{\mathrm{b}}$ \\
Glycogen $^{\#}$ & $0.3029 \pm 0.0776$ & $0.1446 \pm 0.0280$ & $0.8607 \pm 0.1576$ \\
Total Lipids & $0.0119 \pm 0.0021$ & $0.0144 \pm 0.0078$ & $0.0202 \pm 0.0047$ \\
Triglycerides & & & $0.7067 \pm 0.6379$ \\
HP DIET & $0.0118 \pm 0.0009$ & $0.0116 \pm 0.0039^{\mathrm{a}}$ & $0.0203 \pm 0.0022$ \\
Free Glucose & $0.0111 \pm 0.0039$ & $0.0002 \pm 0.0001^{\mathrm{a}}$ & $0.0083 \pm 0.0019^{\mathrm{b}}$ \\
Glycogen & $0.2105 \pm 0.0284$ & $0.5693 \pm 0.1369$ & $0.4769 \pm 0.1194$ \\
Total Lipids & $0.0090 \pm 0.0018^{\mathrm{ab}}$ & $0.1369 \pm 0.0415^{\mathrm{ade}}$ & $0.0098 \pm 0.0039^{\mathrm{df}}$ \\
Triglycerides & & & $0.0270 \pm 0.0052^{\mathrm{ab}}$ \\
\hline
\end{tabular}

glycogen contents in Winter, and glycogen decreased in Summer. There was a significant difference $(\mathrm{p}<0.05)$ in glycogen content between the crayfish treated with the two diets (Tab. III). In animals fed the HC and HP diets, the content of total lipids in the muscle tissue showed no seasonal variation $(p>0.05)$. However, triglycerides showed a seasonal variation only in the group which received HP diet: concentrations were lowest in Spring and highest in Summer. There was a significant difference in triglyceride content $(\mathrm{p}<0.05)$, but not in total lipids $(p>0.05)$, between animals fed the two diets.

\section{DISCUSSION}

Diets (HC or HP) determined the different responses to hemolymphatic glucose in these crayfish: glucose increased more in the animals that received a high-carbohydrate diet than in the animals that received a high-protein diet, except in Autumn. A similar metabolic response pattern was previously observed in an estuarine crab and a freshwater anomuran, Chasmagnathus granulatus (Dana, 1851) and Aegla platensis (Schmitt, 1942) respectively, that received the same type of diet for equal experimental periods (KuCHARSKI \& DA Silva, 1991a; FERREIRA et al., 2005).

In the HP group, hemolymphatic glucose levels were lower than those of crayfish in the $\mathrm{HC}$ diets during
Spring, Summer, and Winter, despite the regular supply of food. In view of the lower percentage of carbohydrates contained in this diet, it is possible that the amino acids gained from the diet are being used in the gluconeogenic pathway to maintain minimum glucose levels in the haemolymph, and low levels of glycogen in the different tissues studied, as seen here. OLIVEIRA \& DA SiLva (1997) demonstrated a high gluconeogenic capacity in the hepatopancreas of crabs, fed either protein- or carbohydrate-rich diets. These authors concluded that the gluconeogenic pathway is important for the survival of the estuarine crab (C. granulatus) during periods of wide environmental variations, such as salinity, food scarcity, and dissolved-oxygen levels (OliveIRA et al., 1997, 2001, 2004a, b). Hemolymphatic glucose is the result of the influx of intestinal glucose (VERRI et al., 2001), and from the balance between anabolic (gluconeogenic, glycogenesis and catabolic, glycogenolysis, glycolysis) processes (Chang \& O'ConNor, 1983; Oliveira \& DA SilVA, 1997; Hall \& VAN HAM, 1998).

Freshwater crayfish possess a variety of physiological, ecological, and behavioral adaptations that have allowed them to occupy a wide range of environments and a range of trophic roles. They have been described as omnivores (GROwNS \& RiCHARDSON, 1988; Lodge et al., 1994; Nyström \& Strand, 1996; GutiÉRREZ-Yurrita et al., 1999), detritivores (HESSEN \& 
SkURDAL, 1986), opportunistic omnivores or microphagic detritivors (O'BriEn, 1995), and selective herbivores (CHAMBer et al., 1990). Detritus (mainly of plant origin) often constitutes the majority of gut contents (HESSEN \& SkURDAl, 1986; HogGer, 1988; GoOdARD, 1988; O’Brien, 1995). The feeding habits of $P$. brasiliensis have not been studied.

Independent of the diets (HC or HP), the levels of hemolymphatic proteins varied similarly, with a peak in Autumn and Winter, and a decrease in Spring and Summer. This diet-independent response suggests that these proteins are used in the reproductive period. In environment we observe that this population of parastacids reproduces in Spring and Summer. Studies in other crustaceans have shown seasonal variations in protein content; these variations are correlated with ovarian development, and result from increases in biosynthesis of some proteins, including hormones, enzymes and lipoproteins involved in gonadal maturation (YeHEZKel et al., 2000; Rosa \& Nunes, 2003b).

Independent of the seasons of the year, the levels of hepatopancreatic free glucose and glycogen rose significantly more in the parastacids that received a highcarbohydrate diet than in those that received a highprotein diet. Several studies have verified that different diets (HC and HP) modify significantly the concentrations of free glucose and glycogen in tissues of $C$. granulatus (Kucharski \& Da Silva, 1991a; Vinagre \& Da Silva, 1992; Oliveira et al., 2004a, b).

In the experiments performed during Winter, the administration of a high-carbohydrate diet changed the homeostasis of glycogen, causing an increase in the polysaccharide in all tissues studied, in relation to crayfish in their natural habitat (Dutra et al., 2008). The same response was observed for A. platensis, a crustacean of the limnetic environment, fed with a $\mathrm{HC}$ diet under the same conditions of cultivation (OliverRa et al., 2007). Animals fed a protein-rich diet had similar glycogen levels in the hepatopancreas, gills and muscle, to animals studied in the field, at the same time of the year (DUTRA et al., 2008).

The storage location of glycogen varies according to the species of crustaceans (JOHNSTON \& DAVIES, 1972; HERREID \& FULL, 1988). The absence of a central glycogen deposit seems to be an adaptation of several classes of animals to changes in environmental factors (НосHACHKA et al., 1970). The stored glycogen is utilized in adaptation to molting, hypoxia and/or anoxia, osmoregulation, growth, in different stages of reproduction and during fasting periods (CHANG \& O'CONNOR, 1983; KUCHARSKI \& Silva, 1991a, b; Oliveira et al., 2001, 2004a).

The results presented here suggest that lipids (total lipids and triglycerides) are the principal form of energy reserves in these parastacids. This supposition is reinforced by the results observed for the different diets (HC and HP). Lipids are the largest power supply in marine invertebrates including shrimps and crayfish, and are involved in basic processes for growth, change, and reproduction (e.g. ovarian maturation, spawning) (Rosa \& Nunes, 2003a), although few studies have been done on parastacids (DuTRa et al., 2008; Silva-CASTIGLIONi et al., 2007).
The increase in carbohydrate content in the diet caused an increase in the reserves of lipids and triglycerides in all the tissues studied. Independent of the diets and levels of storage of total lipids as well as triglycerides, carbohydrates were accumulated in the different tissues in Autumn or Winter, to be used in Summer or Spring. These results suggest that these reserves are important for the reproductive period (Spring and Summer). Hernandez-Vergara et al. (2003) evaluated the effect of different concentrations of lipids in artificial diets offered to the crayfish Cherax quadricarinatus (Von Martens, 1868), and concluded that males invest their lipid reserves in growth, whereas females, with a higher hepatossomatic index, invest in gonadal development and vitellogenesis.

Parastacus brasiliensis, like other crayfishes, produces large, lecithotrophic eggs (FARMER, 1974). The egg size is related to maternal investment, mainly the lipid metabolism (Rosa \& NunEs, 2003a, b). Lipids are the main source of energy throughout embryonic development, and the amount of lipids is generally correlated with the size of eggs and the time interval between spawning and hatching (Petersen \& ANGer, 1997; Rainuzzo et al., 1997). In $P$. brasiliensis we observed that development is direct and the juveniles remain on the pleopods of the female until 9 days after eclosion, and then separate gradually over about 4 days.

Independent of the diet offered to the animals, we observed that the 15 days period feeding the different diets, with temperature $\left(25^{\circ} \mathrm{C}\right)$ and photoperiod $(14 \mathrm{~h}$ light: $10 \mathrm{~h}$ dark) held constant, did not modify the seasonality patterns usually observed in the natural environment (Dutra et al., 2008), and usually related to the reproductive period of the species. However, the highcarbohydrate diet significantly increased the free glucose, glycogen and triglyceride levels in all tissues analyzed. In the haemolymph, the same response was not observed for total proteins, lipids, and triglycerides; only for glucose levels was this pattern observed, regardless of the season the experiment was done. A similar response was reported by Ferreira et al. (2005) studying $A$. platensis fed for 15 days on a high-carbohydrate or highprotein diet in controlled laboratory conditions.

Several studies have evaluated maturation, eye ablation (SAGi et al., 1997; WONGPRASERT et al., 2006), use of hormones (ABDu et al., 2001), fecundity (KING, 1993), and reproductive cycle (SERRANO-PINTO et al., 2004) of the redclaw crayfish under laboratory conditions. Different diets have been used in these studies. Diet plays an important role in crayfish broodstock condition (HoLDICH, 2002). Broodstock nutrition is important for reproductive success, because egg and larval production are strongly dependent on the diets offered (BROMAGE, 1995; Harrison, 1997; García-UlloA, 2000). Protein is the most critical ingredient in practical diets, because it is expensive and growth responses are affected (CORTÉsJACINTO et al., 2003; THOMPSON et al., 2005). According to HARRISON (1997), the amount of protein required in broodstock diets for maturation and production of eggs is higher than the level required for grow out, because gonad maturation is a process of intense protein synthesis, mainly during vitellogenesis (ABDu et al., 2000). 
Our results showed that the $\mathrm{HC}$ diet increased all energy reserves in adult parastacids. This may improve reproduction (fecundity and egg quality), which remains to be investigated. RADFORD et al. (2005) showed in juveniles rock lobsters of Jasus edwardsii (Hutton, 1875) the importance of carbohydrates in artificial diets. In conclusion, the metabolic responses in crayfish fed HC and HP diets provided valuable information concerning the suitability of carbohydrates for inclusion in artificial diets in parastacids and other crustaceans.

Acknowledgements. This work was supported by the Fundação de Amparo à Pesquisa do Rio Grande do Sul (FAPERGS) Grant N ${ }^{\circ}$. 01509093. The Pontifícia Universidade Católica do Rio Grande do Sul also supported this work. The experiments were performed according to the current Brazilian laws.

\section{REFERENCES}

Abdu, U.; Yehezkel, G. \& Sagi, A. 2000. Oocyte development and polypeptide dynamics during ovarian maturation in the redclaw crayfish Cherax quadricarinatus. Invertebate Reprodutive Development 37:75-83.

Abdu, U.; Barki, A.; Karplus, I.; Barel, S.; TAKac, P.; Yehezkel, G.; Laufer, H. \& SAGI, A. 2001. Physiological effects of methyl farnesoate and pyriproxyfen on wintering female crayfish Cherax quadricarinatus. Aquaculture 202:163-175.

Almeida, A. O. \& Buckup, L. 1999. Caracteres sexuais primários e secundários do lagostim Parastacus defossus Faxon, 1898 (Crustacea, Parastacidae). Nauplius 7:113-126.

Bromage, N. 1995. Broodstock management and seed quality general considerations. In: Bromage, N. R. \& Roberts, R. J. eds. Broodstock Management and Egg and Larval Quality. Oxford, Blackwell Science. p.1-24.

Buckup, L. \& Rossi, A. 1980. O gênero Parastacus no Brasil (Crustacea, Decapoda, Parastacidae). Revista Brasileira de Biologia 40:663-681.

Buckup, L. 1999. Família Parastacidae. In: Buckup L. \& BondBuckup G. eds. Os Crustáceos do Rio Grande do Sul. Porto Alegre, UFRGS. p.319-327.

Campaña-Torres, A.; Martinez-Cordova, L. R.; VillarrealColmenares, H. \& Civera-Cerecedo, R. 2005. In vivo dry matter and protein digestibility of three plant-derived and four animalderived feedstuffs and diets for juvenile Australian redclaw, Cherax quadricarinatus. Aquaculture 250:748-754.

CARR, R. S. \& NEFF, J. M. 1984. Quantitative semi-automated enzymatic assay for tissue glycogen. Comparative Biochemistry and Physiology 77B:447-449.

Chamber, P. A.; Hanson, J. M.; Burke, J. M. \& Preas, M. M. 1990. The impact of the crayfish Orconectes virilis on aquatic macrophytes. Freshwater Biology 24:81-91.

Chang, E. \& O'Connor, J. D. 1983. Metabolism and transport of carbohydrates and lipids. In: MAntell, L. H. ed. The Biology of Crustacea: Internal Anatomy and Physiological Regulation. New York, Academic. p.263-287.

Cortés-Jacinto, E.; Villarreal-Colmenares, H.; Civera-Cerecedo, R. \& Martínez-Córdova, R. 2003. Effect of dietary protein level on growth and survival of juvenile freshwater crayfish Cherax quadricarinatus (Decapoda: Parastacidae). Aquaculture Nutrition 9:204-207.

Cortés-Jacinto, E.; Villarreal-Colmenares, H.; Civera-Cerecedo, R. \& Naranjo-Páramo, J. 2004. Effect of dietary protein level on the growth and survival of pre-adult freshwater crayfish Cherax quadricarinatus (von Martens) in monosex culture. Aquaculture Research 35:1-71.

Drach, F. \& TchernigovtzefF, C. 1967. Sur la method de determination des stades d'intermude et son application générale aux crustacés. Vie Milieu 161:595-607.

Dutra, B. K.; Zank, C.; Da Silva, K. M.; Conter, M. R. \& Oliveira, G. T. 2008. Seasonal Variations in the intermediate metabolism of the crayfish Parastacus brasiliensis (Crustacea, Decapoda, Parastacidae) in the natural environment and experimental culture. Iheringia, Série Zoologia, 98(3):355-361.

FARMER, A. S. D. 1974. Reproduction in Nephrops norvegicus (Decapoda: Nephropidae). Journal of Zoology 174:161-183.

Ferreira, B. D. P.; Hack, C. S.; Oliveira, G. T. \& Bond-Buckup G. 2005. Perfil metabólico de Aegla platensis Schmitt, 1942
(Crustacea, Anomura) submetida a dietas ricas em carboidratos ou proteínas. Revista Brasileira de Zoologia 22:161-168.

Folch, J.; Lees, M. \& Sloane-Stanley, G. H. 1957. A simple method for isolation and purification of total lipids from animal tissues. Journal of Biological Chemistry 226:497-509.

FontouRA, N. F. \& Buckup, L. 1989. O crescimento de Parastacus brasiliensis (Von Martens, 1869) (Crustacea, Decapoda, Parastacidae). Revista Brasileira de Biologia 49:897-909.

Fries, B. G. 1980. Observações sobre o lagostim de água doce Parastacus brasiliensis (von Martens, 1869) em condições de cultivo experimental em laboratório (Crustacea, Decapoda, Parastacidae). Revista Brasileira de Biologia 44:409-416.

Frings, C. S. \& DunN, R. T. 1970. A Colorimetric Method for Determination of Total Serum Lipids Based on the Sulfophosphovanillin Reaction. American Journal of Clinical Pathology 53:89-91.

Garcia-Guerrero, M.; Racotta, L. S. \& Villarreal, H. 2003. Variation in lipid, protein, and carbohydrate content during the embryonic development of the crayfish Cherax quadricarinatus (Decapoda:Parastacidae). Journal of Crustacean Biology 23:1-6.

García-Ulloa, G. M. 2000. Fundamentos de nutrición acuícola. Editorial Folia Universitaria. Guadalajara, Jalisco, Mexico, Universidad Autónoma de Guadalajara. 221p.

García-Ulloa, G. M.; López-Chavarín, H. M.; RodríGuez-González, H. \& Villarreal-Colmenares, H. 2003. Growth of redclaw crayfish Cherax quadricarinatus (Von Martens 1868) (Decapoda: Parastacidae) juveniles fed isoproteic diets with partial or total substitution of fish meal by soya bean meal: preliminary study. Aquaculture Nutrition 9:1-25.

Geary, N.; Langhans, W. \& Scharrer, E. 1981. Metabolic concomitants of glucagon-induced suppression of feeding in the rat. American Journal of Physiology 241:R330-R335.

Goodard, J. S. 1988. Food and feeding. In: Holdich, D. M. \& LOWERY, R. S. eds. Freshwater crayfish: Biology, management and exploration. Portland, Timber. p.145-166.

Growns, I. O. \& Richardson, A. M. M. 1988. Diet and burrowing of the freshwater crayfish, Parastacoides tasmanicus tasmanicus Clarck (Decapoda, Parastacidae). Australian Journal of Marine Freshwater Biology Research 39:525-534.

Gutiérrez-Yurrita, P. J. \& Montes, C. 1999. Bioenergetics and phenology of reproductive of the introduced red swamp crayfish, Procambarus clarkii, in Doñana National Park, Spain, and implications for species management. Freshwater Biology 42:561-574.

Hall, M. R. \& VAn Ham, E. H. 1998. The effects of different types of stress on blood glucose in the giant tiger prawn Penaeus monodon. Journal World Aquatical Society 29:290-296.

HARRISON, E. K. 1997. Broodstock nutrition and maturation diets. In: D'Abramo, L. R.; Conklin, D. E. \& Akiyama, D. M. eds. Crustacean Nutrition. Baton Rouge, World Aquaculture Society. p.390-410.

Hernandez-Vergara, M. P.; Rouse, D. B.; Olvera-Novoa, M. A. \& Davis, D. A. 2003. Effects of dietary lipid level and source on growth and proximate composition of juvenile redclaw (Cherax quadricarinatus) reared under semi-intensive culture conditions. Aquaculture 223:107-115.

Herreid, C. F. \& Full, R. J. 1988. Energetics and locomotion In: MacMahon, B. ed. Biology of Land Crabs. Cambridge, Cambridge University. p.337-377.

Hessen, D. O. \& SkuRdal, J. 1986. Analysis of food utilized by the crayfish Astacus astacus in Lake Steinsfjord, S. E. Norway. Freshwater Crayfish 6:187-193.

Hochachia, P. W.; Somero, G. N.; Schneider, D. E. \& Freed, J. M. 1970. The organization and control of metabolism in the crustacean gill. Comparative Biochemistry and Physiology 33A:529-548.

HogGer, J. B. 1988. Ecology, population biology and behavior. In: Holdich, D. M. \& LowerY, R. S. eds. Freshwater Crayfish: biology, management and explotation. Portland, Timber. p.114-144.

HoLdich, M. D. 2002. Biology of Freshwater Crayfish. London, Blackwell Science v.702. p.125-138.

Johnston, M. A. \& Davies, P. S. 1972. Carbohydrates of the hepatopancreas and blood tissues of Carcinus. Comparative Biochemistry and Physiology 41B:433-443.

KING, C. R. 1993. Potencial fecundity of redclaw crayfish, Cherax quadricarinatus (von Martens), in culture. Aquaculture 114:237-241. 
Kucharski, L. C. R. \& Da Silva, R. S. M. 1991a. Effect of diet composition on the carbohydrate and lipid metabolism in an estuarine crab, Chasmagnathus granulata (Dana, 1851) Comparative Biochemistry and Physiology 99A:215-218.

Kucharski, L. C. R. \& Da Silva, R. S. M. 1991b. Seasonal variation on the energy metabolism in an estuarine crab, Chasmagnathus granulata (Dana, 1851). Comparative Biochemistry and Physiology 100A:599-602.

Lodge, D. M.; Kershner, M. W.; Aloi, J. E. \& Covich, A. P. 1994. Effects of an omnivorous crayfish (Orconectus rusticus) on a freshwater littoral food web. Ecology 75:1265-1281.

Lowry, O. H.; Rosebrough, N. J.; Farr, A. L. \& Randall, R. J. 1951. Protein measurements with the folin phenol reagent. Journal Biology Chemistry 183:265-275.

Meade, M. E. \& WAtTs, S. A. 1995. Weight gain and survival of juvenile Australian crayfish Cherax quadricarinatus fed formulated feeds. Journal World Aquaculture Society 26:469-474.

Meyer, E. \& Walther, A. 1980. Methods for the estimation of protein, lipid, carbohydrate and chitin levels in freshwater invertebrates. Archive of Hydrobiology 113:161-177.

Muzinic, L. A.; Thompson, K. R.; Morris, A.; Webster, C. D.; Rouse, D. B. \& Manomaitis, L. 2004. Partial and total replacement of fish meal with soybean meal and brewer's grains with yeast in practical diets for Australian red claw crayfish Cherax quadricarinatus. Aquaculture 230:359-376.

National Research Council. 1985. Guide do the Care and Use of Experimental Animals. A Report of the Institute of Laboratory Animal Resource Committee on the Care and Use of Laboratory Animals. NIH Publication no. 85. Washington D.C.: U.S. Department of Health and Human Services.

Nyström, P. B. \& Strand, J. A. 1996. Grazing by a native and an exotic crayfish on aquatic macrophytes. Freshwater Biology 36:673-682.

O'Brien, B. G. 1995. The natural diet of the freshwater crayfish Cherax tenuimanus (Smith 1912) (Decapoda: Parastacidae) as determined by gut content analysis. Freshwater Crayfish 10:151-162.

O’Connor, J. D. \& Gilbert, L. I. 1968. Aspects of lipid metabolism in Crustaceans. American Zoology 8:529-539.

Oliveira, G. T. \& DA Silva, R. S. M. 1997. Glyconeogeneses in hepatopancreas from Chasmagnathus granulata crabs maintained on high- protein or carbohydrate-rich diets. Comparative Biochemistry and Physiology 118A:14291435 .

Oliveira, G. T.; Eichler, P.; Rossi, I. C. C. \& Da Silva, R. S. M. 2004a. Hepatopancreas gluconeogenesis during anoxia and post-anoxia recovery in Chasmagnathus granulata crabs maintained on high-protein or carbohydrate-rich diets. Journal Experimental of Zoology 301A:240-248.

Oliveira, G. T.; Fernandes, F. A.; Bond-Buckup, G.; Bueno, A. A. \& DA Silva, R. S. M. 2003. Circadian and seasonal variations in the metabolism of carbohydrates in Aegla ligulata (Crustacea: Anomura: Aeglidae). Memoirs Museum of Victoria 60:59-62.

Oliveira, G. T.; Fernandes, F. A.; Bueno, A. A. P. \& Bond-Buckup, G. 2007. Seasonal variations in the intermediate metabolism of Aegla platensis (Crustacea, Aeglidae). Comparative Biochemistry and Physiology A 147:600-606.

Oliveira, G. T.; Rossi, I. C. C. \& DA Silva, R. S. M. 2001. Carbohydrate metabolism during noxia and pos-anoxia recovery in Chasmagnathus granulata crabs maintained on high-protein or carbohydrate-rich diets. Marine Biology 139:335-342.

Oliveira, G. T.; Rossi, I. C.; Kucharski, L. C. \& Da Silva, S. M. 2004b. Hepatopancreas gluconeogenesis and glycogen content during fasting in crabs previously maintained on a highprotein or carbohydrate-rich diet. Comparative Biochemistry and Physiology 137:383-390.

Parvathy, K. 1971. Glycogen storage in relation to the moult cycle in two crustaceans Emerita asiatica and Ligia exotica. Marine Biology 10:82-86.

Petersen, S. \& Anger, K. 1997. Chemical and physiological changes during the embryonic development of the spider crab
Hyas araneus L. (Decapoda: Majidae). Comparative Biochemistry and Physiology 117B:299-306.

Rainuzzo, J. R.; Reitan, K. I. \& Olsen, Y. 1997. The significance of lipids at early stages of marine fish: a review. Aquaculture 155:103-116.

Radford, C. A.; Marsden, I. D.; Davison, W. \& Taylor, H. H. 2005. Haemolymph glucose concentrations of juvenile rock lobsters, Jasus edwardsii, feeding on different carbohydrate meals. Comparative Biochemistry and Physiology A 140:241-249.

RodríGuez-GonZÁlez, H.; García-Ulloa, M.; Hernández-Llamas, A. \& Villarreal, H. 2006. Effect of dietary protein level on spawning and egg quality of redclaw crayfish Cherax quadricarinatus. Aquaculture 257:412-419.

Rosa, R. \& Nunes, M. L. 2003a. Biochemical composition of deep-sea decapod crustaceans with two different benthic life strategies off the Portuguese south coast. Deep-Sea Research Part I 150:119-130.

Rosa, R. A. \& Nunes, M. L. 2003b. Changes in organ indices and lipid dynamics during the reproductive cycle of Aristeus antennatus, Parapenaeus longirostris and Nephrops norvegicus (Crustacea: Decapoda) females from the south Portuguese coast. Crustaceana 75:1095-1105.

Sagi, A.; Shoukrun, R.; Levy, T.; Barki, A.; Hulata, G. \& Karplus, I. 1997. Reproduction and molt in previously spawned and first-time spawning red claw crayfish Cherax quadricarinatus females following eyestalk ablation during the winter reproductive-arrest period. Aquaculture 156: 101-111.

Schirf, V. R. ; Turner, L. S. ; Hanapel, C. ; De La Cruz, P. \& Dehn, P. F. 1987. Nutritional status and energy metabolism of crayfish (Procambarus clarkii, Girardi) muscle and hepatopancreas. Comparative Biochemistry and Physiology 88A:383-386.

Serrano-Pinto, V.; Landais, I; Ogliastro, M. H. Gutierrez-Ayala, M.; Mejia-Ruiz, H.; Villarreal-Colmenares, H.; García-Gasca, A. \& VAZQUEZ-BoucARD, C. 2004. Vitellogenin mRNA expression in Cherax quadricarinatus during secondary vitellogenic at first maturation females. Molecular Reproduction Development 69: $17-21$.

Silva-Castiglioni, D.; Dutra, B. K.; Oliveira, G. T. \& Bond-Buckup, G. 2007. Seasonal variations of the intermediate metabolism of Parastacus varicosus Faxon, 1898 (Crustacea, Decapoda, Parastacidae). Comparative Biochemistry and Physiology A $148: 204-213$.

Thompson, K. R.; Muzinic, L. A.; Engler, L. S.; Morton, S. \& Webster, C. D. 2004. Effects of feeding practical diets containing various protein levels on growth, survival, body composition, and processing traits of Australian red claw crayfish (Cherax quadricarinatus) and on pond water quality. Aquaculture Research 35:647-659.

Thompson, K. R.; Muzinic, L. A.; Engler, L. S. \& Webster, C. D. 2005. Evaluation of practical diets containing different protein levels, with or without fish meal, for juvenile Australian red claw crayfish (Cherax quadricarinatus). Aquaculture 244:241-249.

VAN HANDEL, E. 1965. Estimation of glycogen in small amount of tissue. Analytical Biochemistry 11: 256-265

Verri, T.; Mandal, A.; Zilli, L.; Bossa, D.; Mandal, P. K.; Ingrosso, L.; Zonno, V.; Vitella, S.; Ahearn, G. A. \& Storelli, C. 2001. DGlucose transport in decapod crustacean hepatopancreas. Comparative Biochemistry and Physiology 130A:585-606.

Vinagre, A. S. \& DA Silva, R. S. M. 1992. Effects of starvation on the carbohydrate and lipid metabolism in crabs previously maintained on a high-protein or carbohydrate-rich diet. Comparative Biochemistry and Physiology 102A:579-583.

Wongprasert, K.; Asuvapongpatana, S.; Poltana, P.; Tiensuwan, M \& Withyachumnarnkul, B. 2006. Serotonin stimulates ovarian maturation and spawning in the black tiger shrimp Penaeus monodon. Aquaculture 260:315-325.

Yehezkel, G.; Снауотh, R.; Abdu, U.; Khalaila, I. \& Sagi, A. 2000 High-density lipoprotein associated with secondary vitellogenesis in the haemolymph of the crayfish Cherax quadricarinatus. Comparative Biochemistry and Physiology 27B:411-421. 